\title{
梅 毒血清反応の検討
}

— FTA-ABS, TPHA を中心として—

\author{
愛知県衛生研究所（所長:福田常男博士） \\ 太田秀夫 松井博 範 \\ （西枇杷島保健所）
}

斉 藤 四 郎

（田原保健所）

彦坂治

\section{I. まえがき}

梅毒の血清反応は従来よりカルジオライピン (以下，C L) の抗原を使用する反応が一般に実施 されているが，これはあくまでレアギン反応であ り，その感度は非常に高いが，それと反対に非 特異反応すなわち生物学的偽陽性 biological false positive reaction, (BFP) の出現がある,この B F P を解消するには梅毒の直接病原体 Treponema Pallidum（以下 T P) を抗原とする反応によるほか はないとして，いろいろ T P 抗原による反応が開 発されたが, 病原体の供給, 技術的の煩雑さによ つて一般化されない反応が多い。しかし，近時開

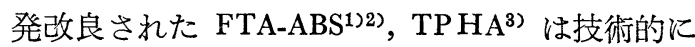
少々の難は残されているが，すでに試薬として一 般に市販される段階となつた。これらの反応によ る特異性, 鋭敏性は非常に高く,すぐれているこ とは衆知のごとくである.

われわれは梅毒患者血清について C L 抗原によ る 3 法 (緒方法, 凝集法, ガラス板法) と T P抗 原による FTA-ABS, TPHA との比較検討, とく に晚期潜伏梅毒血清に対する FTA-ABS，TPHA の反応経過らについて述べる.

\section{II. 実験材料および方法}

1. 供試血清, 1966年～1968年の 3 カ年に一般 病院, 県下保健所より送られてきたもので診断の 明記された 217例 (早期梅毒21例, 晚期潜伏梅毒 172例, 先天性梅毒24例) を実験に供した。なお， 同一人の重複はチェックにより除去した。
2. 実験方法, C L 3 法の使用抗原は住友化学 製を使用した。 T P抗原による FTA-ABS は血清 稀釈 5 倍, 20 倍で判定した，抗原は国立予防衛生 研究所より分与された TP, Nichols 株浮游液を凍 結乾燥したものを使用した。吸収液はB B L 社製 の FTA-ABS. 吸収液と, 富沢ら"の方法により自 家作製したのを使用した。 蛍光標識抗体は東大医 科学研究所製と一部栄研化学ロットNE 009Cを 使用した. 蛍光観察装置は千代田蛍光顕微鏡 F M $200 \mathrm{~A}$ を使用し,すべてUV励起方式によつた。 T P H A は富士臟器製で使用書に従つて行なつた。

\section{III. 実験成績}

1. 各血清反灾の病期別陽性率

C L 抗原による 3 法は各病期梅毒とも凝集法の 陽性率がもつとも低く, ガラス板法, 緒方法と高 かつた. T P 抗原による 2 法は早期梅毒, 先天性 梅毒とも 100\%陽性, 晚期潜伏梅毒は FTA-ABS が97.7\%，T P HAが94.2\%で，FTA-ABS が高 い陽性率にみられた（表 1)。

2. FTA-ABS と T PHAの一致率

早期梅毒, 先天性梅毒では 100\%の一致をみ, 晚期潜伏梅毒では95.3\%の一致をみた。不一致は FTA-ABS 陽性, T P H A 陰性 7 例 ( $4.1 \%), T$ P H A 陽性, FTA-ABS 陰性 1例 ( $0.6 \%)$ でい ずれも晚期潜伏梅毒例のみであつた（表 2).

\section{3. 梅毒患者症例}

症例 1 ：30才，令，晚期梅毒 (図 1). C L 法は 5 カ年にわたり検査したがガラス板法は 2 年後に 
表 1 病期別血清反応陽性率

\begin{tabular}{|c|c|c|c|c|c|c|}
\hline \multirow{2}{*}{ 診 } & \multirow{2}{*}{ 例数 } & \multicolumn{3}{|c|}{$\mathrm{C} \mathrm{L}$ 抗 原 } & \multicolumn{2}{|c|}{$\mathrm{P}$ 抗 } \\
\hline & & 凝 集法 & ガラス板法 & 緒 方 法 & FTA-ABS & ГРНА \\
\hline 早 期 梅 毒 & 21 & $18(85.7)$ & $20(95.2)$ & $20(95.2)$ & $21(100.0)$ & $21(100.0)$ \\
\hline 晚期潜伏梅毒 & 172 & $159(92.4)$ & $160(93.0)$ & $164(95.3)$ & $168(97.7)$ & $162(94.2)$ \\
\hline 先 天 性 梅 毒 & 24 & $22(91.7)$ & $22(91.7)$ & $23(95.3)$ & $24(100.0)$ & $24(100.0)$ \\
\hline 計 & 217 & $199(91.7)$ & $202(93.1)$ & $207(95.4)$ & $213(98.2)$ & $207(95.4)$ \\
\hline
\end{tabular}

表 2 FTA-ABS·TPHA の一致率

\begin{tabular}{|c|c|c|c|c|c|}
\hline \multirow{2}{*}{ 診断 } & \multirow{2}{*}{ 例数 } & \multicolumn{4}{|c|}{ FTA-ABS -TPHA } \\
\hline & & $+\cdot+$ & $+\cdot-$ & $-\cdot+$ & $-\cdot-$ \\
\hline 早 期 梅 毒 & 21 & $21(100.0)$ & 0 & 0 & 0 \\
\hline 晚期潜伏梅毒 & 172 & $161(93.6)$ & $7(4.1)$ & $1(0.6)$ & $3(1.7)$ \\
\hline 先天性梅 毒 & 24 & $24(100.0)$ & 0 & 0 & 0 \\
\hline 計 & 217 & $206(94.9)$ & $7(4.1)$ & $1(0.6)$ & $3(1.7)$ \\
\hline
\end{tabular}

図 1 症例 1.30才。令。晚期梅毒
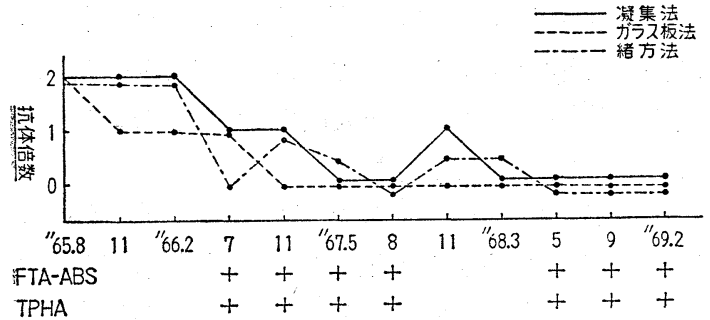

陰転. 他の 2 法は陰転, 陽転と繰り返しみられ たが，最近 3 回の成績は陰性であつた. FTA-ABS， TPHA は検査 4 回目より実施したが毎回陽性で 陰転は全くみられなかつた。

症例 $2: 28$ 才, 우, 晚期梅毒 (図 2). 3 力年に わたり検査したが，CL法は陽性が続き，陰転は みられなかつたＦTA-ABS はCL法と同じく陽 性が続いたが，T P HAは毎回陰性が続いた例 で，T P抗原を使用する反応の不一致例として注 目すべき症例であつた。

症例 $3: 71$ 才, 우, 梅毒の疑. 4 力年にわたり 梅毒の疑として依頼されたが，CL 3 法は不一致 で, ガラス板法のみ陽性が続き，凝集法は第 1 回
図 2 症例 2 . 28才, 우. 晚期梅毒

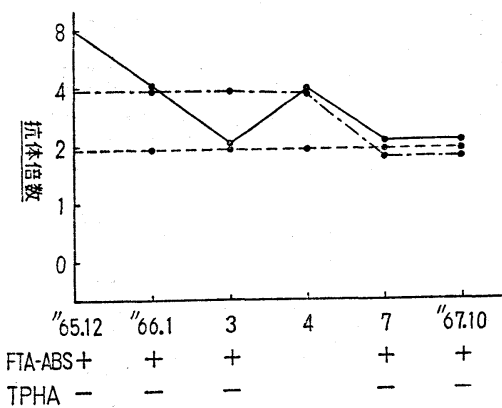

が陽性, 以後陰転 している. 緒方法 は陽性（定 量価 5 倍)，陰性と繰り返しみられた。FTA-ABS, TPHA はともに陰性であつた（図 3 ）。

図 3 症例 3.71 . 才우. 梅毒の嶷

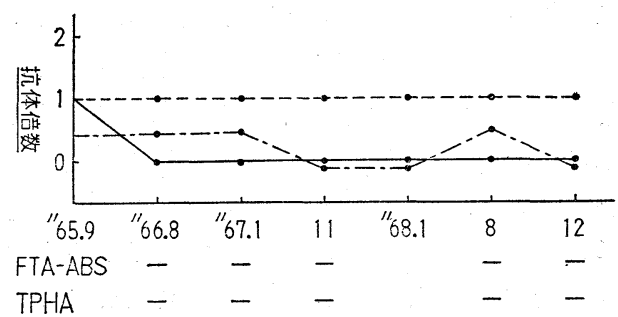




\section{IV. 考 察}

梅毒の血清反応ではその特異性, 鋭敏性は必ず 問題となるが，最近開発改良された T P 抗原によ る FTA-ABS，TPHA の実用化により梅毒血清診 断法は大きく飛躍した. Hunter らは FTA-ABS の鋭敏度は第 I 期梅毒 $80.7 \%$ ，未治療あるいは不 完全治㞠晚期梅毒で 100\%とし，特異度について も完全な成績が壳られたとしている，Deacon ら5) は未治療群执よび治療群について FTA-ABS は第 I 期梅毒 $85.3 \%$ ，第 II 期梅毒 $89.9 \%$, 晚期梅毒, 先天性梅毒 $94.9 \%$ の鋭敏度で特異度も完全な成績 であつたと述べている，Knoxら ${ }^{6)} ，$ Harnerら ${ }^{7}$, Atwood $5^{8}$ の成績によつても鋭敏度，特異度と も同じく高い成績であつた. 水岡ら ${ }^{9}$ は確実な梅 毒50例で70\%の陽性率であつたとしている. T P H A では富沢 ${ }^{10)}$ は各期梅毒で $98.1 \%$, 進行麻疩 97 $\%$ の鋭敏度, 健康者 $98.9 \%$, 妊婦 $100 \%$ の特異度 であつたとしている. 太田ら 婦で 100\%の特異度をみた. 今回は 217 例の梅毒 患者病期別についてみたが FTA-ABS, TPHA の 成績では早期梅毒および先天性梅毒で 100\%, 晚 期潜伏梅毒は FTA-ABS 97.7\%, T P H A 94.2\% の陽性率をみたが，いずれも鋭敏度，特異度とも 同様の成績であつた。

T Pを抗原とする 血清反応の比較検討をみる と, Knox ら で, 不一致は FTA-ABS 陽性, T P I 陰性 6.3 $\%$, 反対例は0.36\%で FTA-ABS が特異的血清反 応であるとしている. AtwoodらろもFTA-ABS·TPI で94\%の一致率で FTA-ABS 陽性, T P I 陰性 9 $\%$, 反対例はなく T P I よりFTA-ABS が鋭敏度に まさり，特異度は同じであるとしている. Deacon ら5)は VDRL, TPI, FTA-ABS の比較成績で鋭敏 性に FTA-ABS が一番すぐれていたが，CLによ る B F P, その他の血清群で16\%陽性が出ている ことは注目すべきである。富沢 ${ }^{10)}$ は T P H A FTA-ABS と同じく特異度, 鋭敏度ともにすぐれ ているが，血清反応の宿命で正常抗体の所有を完 全にとり除く、いわゆる Reiter 株 T Pのみの吸 収は不完全と考兄られるとし，特異性をよくする
には病原 T P の精製も考慮しなければならないと 述べている。われわれの FTA-ABS と T P HAの 一致率をみた成績では95.3\%と，T P I と FTA$\mathrm{ABS}$ の一致率よりやや高い成績であつた。 これは FTA-ABS の鋭敏度と同じく T P H A 鋭敏度が T P I よりややすぐれていることを示唆すべきで ある. しかし，FTA-ABS と T P I とに不一致を みたごとく， T P HAにも不一致例が $4.6 \%$ あ り，この症例はいずれも晚期潜伏梅毒例にみられ 長期観察したものでC L 法, FTA-ABS は毎回陽 性, T P H A 毎回陰性であつたもので, これら より T PHAの鋭敏性について速断はさけるべき であるが，両者の反応に関与する抗体自体が部分 的にやや異なつていることが考光られる。また， 不一致例が晚期潜伏梅毒例であつたことより，長 期にわたる梅毒の自然経過や, 治療による経過観 察中のため, それぞれ関与する抗体消長の差異ら が考えられる.な执，関与する抗体自体の問題に ついては今後の研究にゆずりたい.

\section{v. ま ぬ め}

C L 3 法と FTA-ABS, TPHA について明らか に梅毒と診断されている 217例 (早期梅毒21例, 晚期潜状梅毒 172 例, 先天性梅毒 24 例) にて比較 検討し, 次の結果を得た。

1. 梅毒病期別陽性率で FTA-ABS，TPHA は 早期梅毒, 先天性梅毒とも飞 $100 \%$ 陽性, 晚期潜 伏梅毒で FTA-ABS 97.7\%，T P H A $94.2 \%$ の陽 性であつた。

2. FTA-ABS, TPHA の一致率は早期梅毒, 先天性梅毒で 100\%，晚期潜伏梅毒では95.3\%で あつた。，不一致は晚期潜伏梅毒例のみで，FTAABS 陽性, T P H A 陰性 4.1\%, 反対例 $0.6 \%$ で あつた。

3. 梅毒の治癒判定, 経過観察中の症例にはC L法によるのが適当であり，FTA-ABS，TPHAで は抗体価の変動は少なく不適当と思われた。 しか 乙, 問題のある血清や， B F P の鑑別にはきわめ て有田である.

（本論文の要旨は第 6 回日本細菌学会中部総会汇 発 表した.) 


\section{参 考}

1) Hunter, E.F., Deacon, W.E. and Meyer, P.E.: An improved FTA test for syphilis, the absorption procedure (FTA-ABS). Pub. Hlth. Reports. 79: 410-412, 1964.

2) 村田道里, 桂 陽子, 加藤幸一ら：螢光抗体法 (吸収法) 一一 F T A-A B S一による梅毒の診 断に関する研究, 日本臨床, $26: 466$-474, 1968.

3) Tomizawa, T. and Kasamatsu, S.: Hemagglutination tests for diagnosis of syphilis. Jap. J. Med. Sei. and Biol., 19: 305-308, 1966.

4) 富沢孝之, 笠松重雄, 山屋駿一, 山田正次 : 梅 毒の血清診断法に関する知見補遺, 第 1 報, Treponema Pallidum [Reiter 株の特異性につい て, 日細学誌, $21: 251-255,1966$.

5) Deacon, W.E., Luces, J.B. and Price, E.V.: Fluorescent treponemal antibody-absorption (FTA-ABS) test for syphilis. JAMA., 198: 624-628, 1966.
6) Knox, J.M., Short, D.H., Wende, R.D. and Glicksman, J.M.: The FTA-ABS test for syphilis performance in 1033 patients. Brit. J. Vener. Dis., 42: 16-20, 1966.

7) Harner, R.E., Smith, L. and Israel, C.W.: The FTA-ABS test in late syphilis. JAMA., 203: 545-548, 1968.

8) Atwood, W.G., Miller, L. Stout, G.W. and Norins, L.G.: The TPI and FTA-ABS tests in treated late syphilis. JAMA., 203: 549-551, 1968.

9) 水岡慶二, 堀越 晃：F T A テストについて, 臨床病理, $16: 21 \sim 26,1968$.

10) 富沢孝之: 感作血球凝集反応 ( T P H A) に ついて, 臨床科学, 4:324 332, 1968.

11）太田秀夫, 斉藤四郎. 古川隆司. 中村 章: 妊婦 梅毒の T P H A, F T A-A B S の有用性, 産 婦人科の世界, $21 ： 740 \sim 745,1969$.

\author{
A Study of FTA-ABS and TPHA \\ Hideo OTA and Hironori MATSUI \\ Aichi Institute of Public Health, Nagoya \\ Shiro SAITO \\ Nishibiwajima Health Center, Aichi Prefecture \\ Osamu HIKOSAKA \\ Tawara Health Center, Aichi Prefecture
}

FTA-ABS and TPHA, especially their specificity and sensitivity as a serum reaction of syphilis, were studied comparing with cardiolipin reaction, using 217 sera samples from patients with syphilis (21 primary syphilis 172 late latent s., and 24 congenital s.). The results were summarized as follows:

1) Sera of primary and congenital s. showed 100\% positivity either by FTA-ABS or TPHA, while those of late latent s. were positive in $97.7 \%$ with FTA-ABS, in 94.2\% with TPHA.

2) Results with FTA-ABS and TPHA were $100 \%$ accorded in primary and congenital s., while in late latent s., $95.3 \%$ : cases with positive FTA-ABS and negative TPHA were $4.1 \%$, and the contrary, $0.6 \%$.

3) For the purpose of diagnosing the healing or following the course of the disease, cardiolipin reaction is preferred, because the new two methods seemed less calibrating in revealing the changing of antibody titers. The two, however, were shown very useful in differentiating biological false positive reaction (BFP) or diagnosing the sera with unreliable results with cardiolipin reaction. 